\section{MERCOSUR: LA BIENAL DE LA DESGLOBALIZACIÓN}

\section{Néstor García Canclini}

RESUMEN: Desde la idea de que los procesos de globalización aprovecham los movimientos globales para crear la infraestructura que fortalezca la base local, abandonando el marco imaginario de las identidades nacionales, el autor analiza la Bienal de Artes Visualesl del Mercosur, 20II. El centra em la propuesta curatorial "Geopoéticas" un cuestionamiento de los conceptos de nacionalidad y centro / periferia.

PALABRAS CLAVE: Globalización, deglobalización, Bienal del Mercosur, geopoéticas.

¿Por qué debe haber una Bienal del Mercosur si no existe un arte mercosureño? Artistas y críticos de Argentina, Brasil, Paraguay y Uruguay han cuestionado incluso que se hable de arte nacional en estos paises. Suena como discriminación que en bienales y ferias de las metrópolis se interpreten las obras de Guillermo Kuitca o Cildo Meireles, más que por sus contribuciones estéticas - según se hace con artistas ingleses 0 alemanes - midiendo cómo representan sus culturas nacionales de origen.

Paradojas de este tipo motivaron que en la $8^{\mathrm{a}}$ Bienal del Mercosur, que se desarrolla del 10 de septiembre hasta el 15 de noviembre de 20II, su curador, José Roca, eligiera como eje conceptual la geopoética. Nacida en 1997 para acompañar la integración económica de los cuatro paises citados, la Bienal logró posicionar a Porto Alegre como foco internacional. Al principio fue discutida por exhibir sobre todo lo que se hace en Brasil, o por la dificultad de representar artísticamente ese proceso de integración regional. Luego de haber estado en la $5^{\text {a }}$ edición y seguir su proceso, veo que se abre ahora a todos los continentes sin repetir los estereotipos del mainstream artístico y académico.

Texto publicado en la Revista $\tilde{N}$ del diario Clarín, el 2 de noviembre de 2011.
Como la propia idea de bienal está cuestionada luego de un siglo de desgaste y por su reciente proliferación mundial (cerca de 200), el catálogo comienza enunciando lo que esta bienal no es: ni una enciclopedia donde se ilustran conceptos ni un archivo para exhibir retóricas curatoriales 0 documentar experiencias que no pudimos ver ni una feria de tecnología a la que se va a mirar las sorpresas que los museos todavía no compraron.

También percibimos que se aleja de las simples oposiciones binarias (centro/periferia, norte/sur) y de la exaltación posmoderna de un nomadismo que descuidaba las diferencias y desigualdades. ¿Cuál es la geopolítica de esta Bienal? Quiere preguntarse de nuevo por lo que hoy pueden ser experiencias no ingenuas de nación, territorio y revolución.

Un primer asombro que ofrece la muestra es la abundancia de banderas: acumuladas, desconstruidas, ironizadas, pero cuya insistencia por sí sola desafía el lugar común de que la globalización habria clausurado lo nacional. Francis Alys presenta dos viejos anuncios de banderas mexicanas con indicación del lugar donde se venden y la sobre impresión "in a given situation": sobre una leemos "representación", sobre otra -idéntica- "espectáculo".

Despliegue de propiedades es el titulo de una de las piezas más potentes: Leslie Shows colgó en lo alto una treintena de banderas blancas de las que chorrean colores, insignias y elementos gráficos. Como estandartes que se derriten y ya no pueden comunicar identidades compactas. Los fragmentos que pueden leerse dejan ver restos de banderas de paises y marcas geográficas 0 señales de tránsito: lo nacional, lo geológico y lo urbano.

Otra pared enorme está cubierta por una bandera negra, titulada Cielo, obra de Luis Romero, que sólo recoge soles, lunas y estrellas de muchas banderas bordadas en hilo blanco. Ni franjas, ni escudos, ni heroicas consignas políicicas; sólo una constelación donde lo que divide es omitido. Aunque el artista dice que algunos espectadores le pidieron eliminar símbolos que refieren a identificaciones religiosas, como señal de intolerancia y quizás, al mismo tiempo, deseo de un imaginario firmamento beatifico donde no haya que hacerse cargo de las diferencias.

Paola Parcerisa exhibe una bandera paraguaya vaciada, en la que sólo los bordes de cada franja están marcados por sutiles hilos de color. Quedan los límites liberados de la contundencia y el emblema central. Averiguo: ¿cómo fue recibida en Paraguay? “La gente común la conoció cuando la llevé a la Bienal de Venecia. Mi hijo de I4 años, cuando estaba haciéndola, preguntó: ¿Es para un partido de fútbol? Cuando la terminé y sólo veía los bordes, entendió así el sentido de que cada franja quedara blanca: "Se fueron todos". 
Las migraciones y las fronteras han estado en el centro de la discusión política y visual sobre lo que queda de las naciones. Los desplazamientos masivos y las represiones fronterizas alimentan, a veces, representaciones melodramáticas o panfletarias. En el extremo opuesto, han incitado obras que reducen la interculturalidad al nomadismo, una circulación fluida de personas y mensajes que disolveria las diferencias.

Algunos artistas combinaron los emblemas nacionales con la iconografía transnacional, como hicieron Melanie Smith y Rafael Ortega en Estadio Azteca. El video mezcla imágenes patrióticas, prehispánicas, de un ídolo de la lucha libre, del arte contemporáneo y de la bebida más famosa, compuestas por centenares de jóvenes que alzan tablas como mosaicos sumados: sugieren no sólo lo que dicen las imágenes sino el disciplinamiento social y su contradictoria 0 fallida realización. Una gran pantalla del estadio, en lo alto de la tribuna, teniendo en los márgenes los logos de Coca-Cola y la cerveza Corona, declara: "The Revolution will not be televised". Como al mismo tiempo esta obra representa a México en la Bienal de Venecia, dice que la tarea de embajador que a veces se encarga al arte se cumple mejor si asume los símbolos históricos entretejidos con la iconografia deportiva, comercial y mediática.

Un mérito de la Bienal del Mercosur es desmarcarse del imaginario de identidades nacionales soberanas. Entre las intervenciones con más eco se halla la del colectivo esloveno creador del Estado NSK, micronación o Estado en tiempo que abre su "consulado" en muchas bienales $y$ entrega pasaportes: largas filas a todas horas para tomarse la foto, llenar el formulario y obtener el documento estaban formadas por gente dispuesta a pertenecer a otra nación inventada 0 acreditarse como miembro de una patria viajera de artistas.

¿El problema es estar insatisfecho con nuestro pais o que las desdichas de unos y otros se parezcan? Kochta \& Kallenein, directores del Coro de Quejas de Teutonia, que han reunido protestas de maltratados por el neoliberalismo, desde Helsinski, su ciudad, hasta Singapur y El Cairo, hicieron una pieza musical con frustraciones de brasileños. Al escuchar a las personas en talleres de quejas encuentran malestares transnacionales, que les dan "la sensación de que ya vivían en esa ciudad hace muchos años".

¿Qué queda, entonces, de las identidades territoriales? Son, más que una representación de algo preciso, una actuación, un modo de posicionarse en la geopolítica mundial. La mayor parte de las obras reflexiona sobre ambigüedades, logros parciales y fracasos, no con banderas y monumentos inamovibles sino con símbolos alterados que miran dudosos a los vecinos (y a si mismos).

No obstante, hubo disconformes. Escuché protestas uruguayas por no estar incluidos. "Pero está la obra de Alberto Lastreto, que vive en Montevideo". "Sí, pero nació en Argentina y últimamente está en Nueva York". ¿Quién está autorizado a representar un pais que figura entre los que cuentan mayor porcentaje fuera de su territorio? Lo responde su obra, El prócer, una figura a caballo videoanimada que salta más allá del pedestal, sobre parques, arcos de fútbol, edificios, con fondos de paisajes de distintos paises, conviviendo con otros monumentos, desde el Arco Trajano hasta la Torre de Tatlin. Erase una época en que los paises se valoraban según fuesen más 0 menos bendecidos por la globalización. Había que abrir la economía a inversiones externas y aumentar las exportaciones; la prosperidad se medía no por indicadores del bienestar de la población nacional (alza de salarios y del consumo), sino por su interdependencia con el mundo y por el equilibrio de la balanza comercial. Algunas regiones comenzaron a sentir frágil la apertura indiscriminada y se agruparon para protegerse: la unificación europea, Mercosur, los tratados de libre comercio 0 entre grupos de paises, como el TLC de América del Norte.

La fragilidad sospechada se convirtió en catástrofe. Si bien esta globalización venía produciendo desde hace dos décadas desempleo y salida de migrantes en el Sur, rechazo a los migrantes y xenofobia en el Norte, caída de las clases medias y peor pobreza en todas partes, el modelo estalló en septiembre de 2008. Habíamos tenido antes cataclismos nacionales (México en 1994, Rusia y otros paises del este europeo al final de esa década, Argentina en 200I), pero en los últimos tres años el derrumbe se mundializa, la Unión Europea exhibe su incapacidad para sostener la integración y Estados Unidos se asoma una y otra vez al precipicio.

¿Salimos del euro? se preguntan los ministros europeos ¿Cómo protegernos del contagio universal? ¿Y del avance chino? Otras dudas semejantes señalan una tendencia a la desglobalización. Los paises del Mercosur, sobre todo Argentina, Brasil y Uruguay, que conocieron hace pocos años los riesgos del abismo, están entre las economías con mejor ritmo de crecimiento anual (7 al $9 \%$ ), se expanden cuidando el desarrollo interno y logran cierta redistribución económica y cultural.

Por supuesto, las artes no son reflejo de los procesos económicos ni políticos. De hecho esta Bienal reúne obras recientes y de años anteriores, como una reflexión de largo plazo. El movimiento internacional del arte, con muchos focos de desarrollo no sólo en las metrópolis, reúne ahora miradas más complejas sobre las articulaciones $y$ fracturas mundiales, desde las revoluciones fallidas a las marchas de los indignados y desesperados de Egipto (Revolución, de Khaled Hafez). A diferencia de quienes conciben una bienal como 
desfile global de las novedades de temporada, la del Mercosur incluye una muestra coordinada por Aracy Amaral, donde artistas actuales revisan las fronteras geográficas y culturales de los paises de la región en diálogo con grabados, esculturas, pinturas de paisajes, objetos domésticos y mapas de expediciones que documentaron otras épocas. Videos, instalaciones sonoras y físicas, fotos satelitales de Google Earth retrabajan el sentido actual de las Misiones, las movedizas fronteras, las mezclas indígenas con portugueses, españoles, africanos, italianos, árabes y judios pobladores de estas tierras.

El programa Ciudad no vista, por otro lado, convocó a artistas brasileños $y$ de otras nacionalidades a intervenir espacios y edificios "poco interesantes" de Porto Alegre: el Observatorio Astronómico, ruinas urbanas, el Viaducto Otávio Rocha, tubos de PVC subidos a diez pilares que amplifican los sonidos del Aeromóvil, tren urbano silencioso que se desplaza por el aire con la fuerza de la presión del vacio y genera reverberaciones necesarias pero que nadie escucha. Santiago Sierra, en cambio, buscó aturdir con los seis altavoces que reproducen los himnos nacionales de los paises del Mercosur tocados al mismo tiempo en los Jardines del Palacio Piratini, antigua sede de los gobernadores portugueses.

No es posible citar ni la mitad de la constelación de talleres y acciones que buscaron incorporar a comunidades alejadas y hacer circular a artistas de otras regiones. Destaco el proyecto pedagógico curado por Pablo Helguera. En vez de difundir información, formó mediadores para que articularan el carácter procesual del trabajo artístico con juegos y reflexiones del público. La investigación, la colaboración y las tareas de interpretación, constitutivas de los trabajos artísticos contemporáneos, eran incentivadas también en los receptores. El curso previo para mediadores formó a 780 universitarios de muchos Estados - no sólo de Porto Alegre- que enseñaron a "responder de forma imaginativa, creativa y flexible" ante las obras. Desglobalizar puede entenderse de dos maneras: incumplir las promesas de integración mundial dejando fuera a paises 0 vastas poblaciones, pero también como el aprovechamiento de movimientos globales para crear infraestructuras locales (fisicas y humanas) que rebasen lo local. Inscribir a artistas, discursos y públicos en intercambios más equilibrados, modificar las maneras de experimentar lo propio y lo de los otros. No sólo ocurría en las obras que representaban naciones ficcionales, sino en las demás reelaboraciones de banderas, mapas, viajes y alianzas donde emergían "zonas de autonomía poética". Se trataba de imaginar las muchas maneras de crear nuestro propio pais.

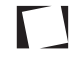

NÉSTOR GARCÍA CANCLINI: Profesor Distinguido en la Universidad Autónoma Metropolitana de México e Investigador Emérito del Sistema Nacional de Investigadores de México. Ha sido profesor en las universidades de Austin, Duke, New York, Stanford, Barcelona, Buenos Aires y Sao Paulo. Su más reciente libro es La sociedad sin relato. Antropología y estética de la inminencia, publicado por Katz Editores. 
